\title{
Novice Teachers' Understandings of the Gap between Teacher Preparation and the Real Classroom in Teaching the Moral Subject in Secondary Schools
}

Young-Eun Kim(Doctoral Student, The University of Texas at Austin)*

\begin{abstract}
$\ll$ ABSTRACT
This study explores novice teachers' experiences between the preservice teacher curriculum (PTC) and the first years of teaching. It aims to critically reflect on teacher preparation of moral subjects, and add empirical qualitative evidence to research in preservice teacher education (PTE). Novice teachers often struggle with their lack of teacher identity and practical knowledge during the first years of teaching. Furthermore, the curriculum mismatch between coursework and the secondary school curriculum hinders knowledge growth in professional teaching. Research data from interviews show that PTC needs a stronger focus on pedagogical content knowledge (PCK) through practice. Moreover, colleges and schools need to collaboratively produce extended student teaching and internship opportunities to preservice teachers.
\end{abstract}

Key Words : preservice teacher education, novice teachers' experiences, learning from practice, sociocultural competence, pedagogical learner knowledge, pedagogical content knowledge

* 교신저자, yekim@utexas.edu 


\section{I . INTRODUCTION}

In a critical reflection on teacher education in secondary moral studies, preservice teacher training is widely regarded as the foundation for a professional teacher; that is, one who is responsive to the needs of current moral education in the classroom as a subject matter. In addition, practice in preservice teacher education (PTE), whether it is based on curriculum or personal experience, strongly affects the first years of teaching. To date, research on teachers of moral subjects pays little attention to how novice teachers make sense of their experiences in relation to the preservice teacher curriculum (PTC). Many studies have examined the PTC along with the enforcement of requirements (e.g., Y.-K. Lee, 2007; Pak, 2007) and suggested improving the teacher training system by focusing on a professional approach to teaching moral subjects (Hwang, 200); however, few studies reflect teachers' experiences and changing backgrounds of students in school and society.

This study begins with a growing interest in the differences in preservice teacher training between the U.S. and Korea. In some sense, the differences probably arise from varying social and cultural contexts. Each idiosyncrasy illustrates, however, the need to reflect on teacher education, particularly preservice teacher training, and remedy its shortcomings. For example, in a comparative study of math teacher education between the U.S. and Korea, Kim, Ham, and Paine (2011) compare the characteristics of math teacher preparation programs in both countries and highlight local variations across different settings. In spite of commonalities in purposes of PTE, they found that while Korea expects a teacher to be more academically prepared as a scholar, the U.S. prepares preservice teachers for diverse students from different social and cultural backgrounds. As a result, while the PTC in the former centers on academic knowledge of subject matter, the latter values learner knowledge and sociocultural understandings with intensive hours of training in the field. As student diversity increases in Korea, teachers now have more opportunities to interact with students whose backgrounds vary in terms of language, culture, ethnicity, race, and class (Cho et al., 2010). Hence, each idiosyncrasy gives insights for specific teacher education of subject matter as well as general teacher education in Korea. Thus, this study is timely given for the necessary re-evaluation of PTE in moral subjects. It is important to note that this study does not rely on comparisons between the two countries, but instead attempts to add empirical literature based on novice teachers' experiences to the reorganization of preservice 
teacher programs.

\section{II . LITERATURE REVIEW AND THEORETICAL FRAMEWORK}

Thornton (1991) contends that teachers are a "curricular-instructional gatekeeper" in that they exert agency over curriculum and instruction decision-making in daily practices. In particular, gatekeeping "based on the idea of teacher agency" (Thornton, 1991, p. 246) is involved in beliefs on the subject matter, curricular planning, and instructional strategy. Conventionally, teachers do not think of themselves as decision makers for curriculum; however Thornton (1991) highlights the significance of teachers' active role in classroom practices and the interactive interface of curriculum and instruction. This idea focuses on how teachers interpret the curriculum in order to promote student learning. Teachers' capability of reorganizing the curriculum to fit students' needs reveals one aspect of professionalization in the subject matter. A teacher is not a just passive receiver of curriculum, but a curriculum agent having authority to develop the curriculum for effective teaching and contribute to the growth of student learning (Carl, 2009).

This ability is not attained through a few courses, but is instead constructed over time through practice. Thus, the PTC should provide an opportunity for student teaching experiences and internships. In this regard, Adler (2008) notes that growing trends in teacher preparation in the U.S. involve an intensive collaboration between university and local schools that link campus coursework with field experience. Particularly, it is novice teachers who hold the vivid experience in PTE when they face the first years of teaching. During this period, they attempt to apply coursework most often in practice. Hence, the first years of teaching are of importance and require further continuous professional development (van Hover, 2008). School-university partnerships provide motivation for college students to consider the teaching profession, extend coursework experiences into practices, and develop professional gatekeeping through appropriate periods during the years of PTE (Heller, 2004). The disparity between teacher preparation and the actual teaching realities tends to confuse novice teachers and ruin their expectations of the teaching profession.

Furthermore, Darling-Hammond (1998) argues for year-long supervised internships, intensive mentoring, and school-based courses to extend the knowledge of students from 
different cultures and backgrounds and deepen the knowledge of subject matter. By increasing the hours of field experience, student teachers gain professional understanding of the social and cultural shifts in learner groups and are able to grow their pedagogical content knowledge (PCK). With the importance of teacher professionalization, student teaching is considered the most significant component in PTC in the U.S. It provides an opportunity to respond to changes of students' demographics and sociocultural backgrounds. Moll \& Arnot-Hopffer (2005) insist:

Teacher education, therefore, is a matter of developing not only technical competence and solid knowledge of subject matter but also sociocultural competence in working with the diversity of students that characterize contemporary schooling (p. 244).

Teaching practices encompass sociocultural understandings of students and contexts where learning takes place. Awareness of how students are culturally and economically situated deepens teachers' knowledge. Teachers' sociocultural competence can evolve to meet the educational needs of the growing multicultural students in Korea. Further, Gay (2005) contends that teacher education should change at the foundational and institutional level in order to focus on social justice as well as cultural diversity. This is not to say that teacher preparation separates cultural competence from pedagogical skills; instead, it asserts that teacher education needs to correspond to the changing social and cultural contexts in teaching. Good instruction and professional teaching largely depends on teachers' beliefs and practical knowledge about the specific subject matter, which is constructed through both life experience and classroom experience (Chant, 2002). As a curriculum developer and instructional decision maker, teachers' beliefs, values, and knowledge have an impact on teaching and instruction (Thornton, 1991). Thus, the differences between the planned curriculum and the implemented curriculum depend mainly on teachers.

Furthermore, teachers' beliefs and ability to transform knowledge to fit students' learning contribute to good instructions (Grossman, 1990; Shulman, 1986). Pedagogical content knowledge (PCK) is constructed through teachers' professional lens, enabling students to easily and effectively understand and access a specific subject matter. Teachers with PCK can construct their own meaningful curriculum for students. As one representation of professionalization, among many different kinds of knowledge, Shulman (1987) discusses PCK in regards to why and how to teach a specific subject matter. As Grimmett and MacKinnon (1992) argue, "Pedagogical content knowledge is derived from a considered 
response to experiences in the practice setting" (p. 387). PCK is not a blend of content and methods; rather it is theoretical and practical integration in teaching a specific subject matter. Therefore, it is necessary that content courses providing core knowledge for preservice teachers are integrated with PCK. In addition to the focus on PCK, teacher preparation programs should provide opportunities for preservice teachers to construct PCK through intensive student teaching.

Kim and others (2011) found that while the U.S. emphasizes instructional knowledge, knowledge about diverse students, and knowledge from field experiences, Korea focuses on content knowledge in mathematics teacher preparation The authors used the terms, content knowledge (CK), pedagogical content knowledge (PCK), pedagogical knowledge (PK), general knowledge (GK), and field experience (FLD) as analytical constructs of curricular program structure. In Korea, teacher preparation is more content-related $(\mathrm{CK}+\mathrm{PCK})$ than pedagogy-related (PK+PCK+FLD) (Kim et al., 2011, p. 56). Specifically, requirements for CK in Korea are two times more than its U.S. counterpart, but requirements for FLD in the U.S. are five times that of Korea.

The integrative request for content and pedagogy is continuously raised in moral teacher preparation. Pak (2007) suggests intensifying PCK in moral education by integrating content and pedagogy, and by increasing requirements focusing on instruction, organizations, and evaluation of moral subjects. Hwang (2007) insists that courses in teacher preparation be linked to the secondary school curriculum of moral studies, and courses related to PCK be increased. Lee (Y.-K. Lee, 2007) argues for teacher preparation programs that entail more requirements in specialization and extended student teaching for two years. Through a historical review of the PTC, Im (2005) highlights that there are few research studies on preservice teacher education curriculum. Furthermore, Bang and others. (1993) draw insights from foreign teacher education and reveal that the PTC is not closely connected to the secondary school curriculum. In addition, they argue that the proportion of both requirements and student teaching is comparatively small. Cha (1995) surveyed teachers of inservice teacher education and showed that they need more programs addressing teaching and instruction. He analyzed the PTC for secondary moral/ethics education and concluded that specialization courses, particularly content courses, were not closely related to the teaching profession. Throughout the past decade, the issues of reinforcing requirements and increasing field experience frequently arise in research of moral teacher education.

Nonetheless, the 17 colleges of education with a department of ethics education uniformly require four credits of field experience. However, as indicated in Table 1, PCK course 
requirements are not given great attention. Examples of PCK courses are: Foundations of Moral/Ethics Education, Teaching Methods in Moral/Ethics Education, Curriculum Development in Moral/Ethics Education, Democratic Citizenship Education, Unification Education, etc. As a result, it is possible for a teacher who has taken only a few PCK courses to teach moral studies in the classroom of a private school. Among specialized courses, PCK courses are relatively less required as well as less frequently provided. Under this context, teachers cannot exert their agency over the national curriculum as a curriculum gatekeeper because they are not trained to implement curriculum and instruction in moral studies.

On the basis of the latest entrance and college regulations, Table 1 shows credit requirements in the PTC in secondary moral subjects in seven random national universities. Teacher knowledge is divided into PCK, CK, PK, FLD, and GK according to Kim et al.'s (2011) and Shulman's (1987) analysis. This analytical frame helps understand how the PTC in the current Colleges of Education for Moral/Ethics Education is structured.

The requests for integration of content and methods in teaching a subject matter, enriched PCK-related requirements, and extended student teaching are prevalent in the relevant studies and research on teacher education in Korea and the U.S. Ultimately, the quality and professionalization of teachers is deeply embedded in the quality of PTE. DeAngelis and others (2013) confirm the importance of both early career support and quality preservice preparation in reducing teacher attrition and turnover rate. Therefore, professional supports such as mentoring and induction programs are needed for beginner teachers. Also, they assert that quality preservice teacher education contributes to addressing teacher attrition since the lack of confidence in teacher preparation is proven to increase the possibility of quitting a teaching job (DeAngleis et al., 2013). Although teaching attrition in the U.S. and Korea is contextually different, the emphasis on quality gives insights to educators and professors in preparing preservice teachers.

It is important to rethink and reflect on the PTC and examine whether it is responsive to moral education as a subject matter in reality. In this regard, this study explores how novice teachers make sense of the gap between teacher preparation and their experiences in schools during the first years. 
〈Table 1〉 Credit Requirement Qualifying for being a Moral Subject Teacher in Secondary School (University names are all pseudonyms.)

\begin{tabular}{|c|c|c|c|c|c|c|c|c|}
\hline \multirow[t]{2}{*}{ Name } & \multicolumn{2}{|c|}{$\begin{array}{l}\text { Compulsory } \\
\text { Specialization }\end{array}$} & \multirow{2}{*}{$\begin{array}{c}\text { Selective } \\
\text { Specialization } \\
\text { PCK+CK }\end{array}$} & \multirow{2}{*}{$\begin{array}{c}\begin{array}{c}\text { Teaching } \\
\text { Requirement }\end{array} \\
\text { PK }\end{array}$} & \multirow{2}{*}{$\begin{array}{c}\text { Student } \\
\text { Teaching } \\
\text { /Volunteer }\end{array}$} & \multirow{2}{*}{$\begin{array}{c}\begin{array}{c}\text { General } \\
\text { Selection }\end{array} \\
\text { GK }\end{array}$} & \multirow{2}{*}{$\begin{array}{c}\text { Teaching } \\
\text { Profession } \\
\text { Total-GK }\end{array}$} & \multirow[t]{2}{*}{ Total } \\
\hline & PCK & CK & & & & & & \\
\hline A & 9 & 15 & 48 & 19 & 4 & 50 & 95 & 145 \\
\hline B & 12 & 21 & 27 & 18 & 4 & 48 & 82 & 130 \\
\hline $\mathrm{C}$ & 8 & 15 & 46 & 20 & 4 & 57 & 93 & 150 \\
\hline $\mathrm{D}$ & 15 & 9 & 42 & 18 & 4 & 62 & 88 & 150 \\
\hline $\mathrm{E}$ & 9 & 21 & 54 & 18 & 4 & 42 & 108 & 150 \\
\hline $\mathrm{F}$ & 8 & 15 & 48 & 18 & 4 & 47 & 93 & 140 \\
\hline G & 3 & 18 & 54 & 16 & 4 & 45 & 95 & 140 \\
\hline Portion & & 44 & -56 & & $2.6 \sim 3$ & & $58 \sim 72$ & $100 \%$ \\
\hline
\end{tabular}

\section{METHODS}

To inquire about how novice teachers of moral subjects make sense of the difference between their experiences in preservice teacher preparation and the first years of teaching experiences in the actual classroom, this qualitative empirical study conducted an in-depth interview of five novice teachers teaching in secondary schools. Using 'purposeful sampling' as 'nonprobability sampling' (Merriam, 2009; Patton, 1990), this qualitative study attempts to particularize teachers' experiences and reflect their voices in the research. In order to "gather contradictory or overlapping perceptions and nuanced understandings that different individuals hold" (Rubin \& Rubin, 2005, p. 67), this study draws five novice teachers, who were trained in the regular PTE and have taught the moral subject in secondary school with a maximum of five years of teaching experience. The small sample size has limitations in generalization. Instead, this qualitative study intends to reflect teachers' real experiences and voices, and draw implications for the relevant research through deep understandings, rather than to generalize the findings.

Participants with pseudonyms consist of one female and four male teachers teaching in different areas in Korea (shown in Table 2). All of the participants graduated from 
Department of Ethics Education in private or national universities from 2006 to 2009. Their teaching experience including temporary teaching amounts to five years. Currently, they are teaching in public or private secondary schools located in metropolitan cities.

The primary data source of this study comes from interviews, which facilitate spontaneous interaction. The interview, guided by the research purpose, consists of semi-structured and open-ended questions (Mears, 2012). In the middle of interview, informal conversation is used to reduce tension (Glesne, 2011). This study consistently takes the stance that "interviews are not neutral tools for data gathering but rather active interactions between two (or more) people leading to negotiated, contextually based results" (Fontana \& Frey, 2005, p. 698). The interview questions are structured to inquire about the teachers' definition of moral education, their identity as a moral teacher, their experiences in the real classroom including teaching and meeting students, their experiences in the PTC, the curricular structure they had taken as requirements, and their own preparation for teaching.

Interviews were conducted from January to February in 2013. Each interview lasted approximately one hour with audio-recordings for transcribing. The entire interview transcript was manually coded and analyzed to search for patterns and themes through comparisons and contrast (Merriam, 2009) using 'thematic analysis' (which does not treat al codes equally). Thematic analysis is useful to interpret data which captures topics and themes of the informants' experiences rather than focusing on the linguistic meaning itself (Glesne, 2011).

$\langle$ Table 2〉 Participants

\begin{tabular}{c|c|c|c|c|c}
\hline Name & Gender & $\begin{array}{c}\text { Type of School } \\
\text { where they are working or } \\
\text { have worked }\end{array}$ & Place of Working & $\begin{array}{c}\text { Teacher } \\
\text { Teaching } \\
\text { Experience } \\
\text { Recruitment } \\
\text { Exam }\end{array}$ \\
\hline Jinyoung & $\mathrm{M}$ & $\begin{array}{c}\text { Public Middle } \\
\text { /Technical High }\end{array}$ & $\begin{array}{c}\text { 'A' } \\
\text { Metropolitan City }\end{array}$ & 4.5 years & Trying \\
\hline Hansol & $\mathrm{M}$ & $\begin{array}{c}\text { Private Middle /Private } \\
\text { General High }\end{array}$ & $\begin{array}{c}\text { 'B' } \\
\text { 'Betropolitan City }\end{array}$ & 5 years & Passed \\
\hline Wooyoung & $\mathrm{M}$ & Public Technical High & $\begin{array}{c}\text { 'B' } \\
\text { Metropolitan City }\end{array}$ & 4 years & Passed \\
\hline Bori & $\mathrm{M}$ & Public General High & $\begin{array}{c}\text { 'A' } \\
\text { Metropolitan City }\end{array}$ & 3 years & Passed \\
\hline
\end{tabular}




\section{RESULTS}

\section{A Mismatch between Current Secondary Curriculum and Teacher Preparation Curriculum}

Participants disclosed difficulties they face when teaching in different settings, such as middle and high school. Since they are not trained for differential teaching in teacher preparation, they are embarrassed to teach moral subjects in new situations. Teacher preparation does not appropriately reflect the current secondary curriculum and instruction, which is strongly visible in participants' experiences. Bori said:

\footnotetext{
Teaching in middle school is totally different from high school. In terms of communication, I feel it's more difficult in middle school than high school. In the former, to make students understand specific knowledge is challenging $\cdots$ In the case of middle school, I had to research more on instructional techniques than contents, focusing on visual and emotional effects.
}

Bori's remark represents participants' lack of readiness in addressing the secondary curriculum. Although they have gained teaching experience through courses and student teaching, these experiences primarily center on only one type of school.

In addition to their lack of training in differential teaching, teachers experience a big gap between the secondary school curriculum and the teacher preparation curriculum. They find that what is learned through coursework does not encompass the school curriculum. Even more so, the learning in teacher preparation is too theoretical and academic-focused. Hence, they are unfamiliar with the new curriculum when they start teaching in the real setting. Aram confirmed:

What we learned from professors about how to manage the classroom and teach students overturned in the real classroom. When I taught the moral subject in middle school, I recognized that I was not at all teaching what I had learned in the preservice teacher program. Moreover, the counseling course is not practical and applicable to real students. Curriculum in teacher preparation is too theoretical and professors are not experts in teaching secondary school curriculum. Some have teaching experiences but others not. 
Leaving instructional knowledge aside, all participants reveal that the curriculum mismatch leads them to disconnected experiences in teaching. According to participants, the teacher preparation program centers on an interest in professors' academic area rather than the curriculum demands of the secondary school. This is not to say that this phenomenon is general or universal throughout teacher preparation. In addition, the gap between the two curriculums might facilitate the teachers' ability to learn through 'trial and error' and to research their own curriculum. However, the curriculum mismatch appears to hinder preservice teachers' readiness in constructing appropriate teacher knowledge. This evidence confirms the problem of teacher preparation pointed out by Hwang (2007, p. 61), who argues that professor-centered curriculum is likely to undermine preservice teachers' professionalization. In this regard, Pak's (2007) suggestion that the moral subject teacher certification should reflect the secondary school curriculum is insightful and timely in reorganizing the PTC. The College of Education should be privileged in teaching and learning. The systematic and consistent curriculum in teaching the moral subject results in teachers' professional development.

\section{The Request on PCK Courses in Preservice Teacher Curriculum}

Participants crave professional knowledge in teaching the moral subject. They understand that teaching the moral subject is different from other subject teaching and are concerned about good teaching practices. As such, they feel a lack of PCK. Hansol said:

\footnotetext{
The hardest thing in teaching the moral subject in the classroom is that we do not know how to teach this subject effectively. Since the university did not train us for practical teaching and instructions suitable for reality, we had to find our own method of teaching. When I went through the variety of methods, such as presentation, video, moral discussion, and cooperative learning, I realized that I was not equipped with the necessary professional knowledge; teaching moral studies is not systematically established in universities.
}

PCK as subject matter knowledge for teaching is constructed through practical experiences over time (Grimmett and MacKinnon, 1992; Shulman, 1987). Depending on the university curriculum, training for the sense of reality is distinct. Participants recalled what courses helped them teach the moral subject in the classroom. Aram listed them: 
Western Philosophy, Ethics, Foundations of Moral Education, Teaching the Moral Subject, Research on Teaching Materials, etc. These courses are practically helpful. In particular, in Teaching the Moral Subject, the professor let us practice teaching in both individual and group settings. The group prepared for teaching while one of the students presented. This really helps.

All participants insisted that they benefited from the courses which led them to practical knowledge in teaching the moral subject. These courses focus on how to teach effectively and why to teach the moral subject. Furthermore, the courses gave them an opportunity to critically reflect on their way of teaching and to develop the teaching curriculum. Wooyoung recalled:

When I took Foundations of Moral Education, I received a lot of bad comments. When we teach an unit in front of preservice teachers, we got feedback. We tend to feel righteous about what we are doing. But it does not make sense. I felt like I did a good job but I got unexpected feedbacks from others. Then I came to understand the importance of public presentations as well as practical experience.

Regarding teaching skills, participants did not mention pedagogical theory courses but instead mentioned PCK courses; they assert that knowing pedagogical knowledge is different from teaching in the classroom. Thus, participants ask that teacher preparation programs reflect more PCK. These courses make the College of Education exist for teacher education, which is different from the college with general majors. Jin and Jo (2001) revealed that PCK courses are not placed in the center of the PTC, although the College of Education should serve teacher preparation for subject matter teaching experts. Given the situation of some students who enter the Department of Ethics Education without teacher identity and inherent motivation, PCK courses throughout the entire curriculum are critical in constructing subject matter knowledge. Jinyoung shared:

At first, I did not want to attend the College of Education. Since I failed in other department that I wanted to study, I could not help but choose this department. It is no wonder that I was not motivated to be a moral subject teacher even during the four years. But after graduation, the Teacher Recruitment Exam was the only choice for my career. I studied for it for a long time. This exam also did not give you a moment to think about being a good teacher. It was merely a test for passing.

Some students chose the Department of Ethics Education based on their scores. Moreover, 
preservice teachers are dealing with the overwhelming focus on test preparation throughout their university career. Given this situation, the teacher preparation program should pay great attention on "subject matter knowledge for teaching" that Shulman argues for to develop teacher identity and knowledge. Otherwise, teachers hardly have the chance to think about being a moral subject teacher and to reflect on their teaching. Hansol, who chose multiple majors with the intent to get more examination chances, said:

\footnotetext{
I barely met a professor who shared teacher identity for why I have to do moral education. To be honest, I myself did not think deeply about being a moral subject teacher during my four years. I know it sounds egocentric, but I was interested in just being a teacher. I heard recently that it has changed and now some professors contribute to the construction of teacher identity and motivation.
}

The data from the interviews shows that the Teacher Recruitment Exam is not necessarily linked with being a good teacher in moral education. According to participants, in addition to the mismatch between the exam and teacher preparation curriculum, competitive and mechanical testing knowledge conflicts with the formation of PCK. Jinyoung confirmed, "In my case as well, I think negatively about this exam. This does not contribute to teacher identity and the practical experience. Its purpose is not to identify a good moral subject teacher but merely for testing." Realistically, preservice teachers appear to focus their university career on taking the exam. As such, valid teacher preparation for teacher professionalization and identity formation is in great demand.

\section{Effective Student Teaching and Internships}

The demand on practical teaching experiences through coursework is extended to the request for student teaching. As a preservice teacher, participants want to have more opportunities to meet students in a real classroom. This is almost the only occasion for them to apply their learning to reality. Professional supervision as well as extension of student teaching is necessary to establish effective links with their courses. Participants enumerated their student teaching experiences. Aram recalled:

I could not teach what I learned from the teacher preparation curriculum. My supervisor prohibited student teachers from teaching Western Philosophy, Eastern Philosophy, or Politics because of the burden of the College Scholastic Ability Test. I 
just taught Environmental Ethics. It was total of three to four hours over the entire student teaching $\cdots I$ could not feel a sense of accomplishment through student teaching.

The quality of student teaching requires professional collaboration between the school and the college (Adler, 2008). This systematic collaboration affects student teachers' values, attitudes, and beliefs, not to mention their teacher knowledge. As shown in Table 1, most teacher preparation programs allocate $2.6 \sim 3 \%$ of credit requirement to student learning and service learning. Even then, service learning does not occur in the real classroom. This contradicts preservice teachers' request. In contrast, in the U.S., being a secondary math teacher generally requires student teaching and internships consisting of $12.73 \%$ of the total credit requirement (Kim et al., 2011, p. 56). Thus, teacher preparation in the U.S. values teacher knowledge through practical experiences. Considering Grimmett and MacKinnon's (1992) notion that PCK is formed through practice and experience, teacher preparation curriculum needs to be reorganized, with special attention on practical experiences. Otherwise, cases of student teachers who ultimately do not practice teaching will increase. Bori shared:

I did student teaching in a high school that was designated by the College of Education. I practiced teaching for a total two hours over the one month. It depends on the supervising teacher; some let student teachers do everything, others not. I felt like one month is too short to gain the feeling of being a teacher.

The request for effective student teaching frequently emerges in academia. Lee (Y.-K. Lee, 2007) suggests the extension of student teaching during five weeks for two years. Bang and others (1993) point out the inefficiency of student teaching two decades ago. Low credits and the short four week term, however, remains unchanged.

Student teachers still learn from their student teaching experience and strive to use it to formulate their teacher identity. Jinyoung added:

Student teaching was really helpful. I hope student teaching is extended. Ultimately, the classroom is where we work. Learning from lectures in teacher preparation is quite different from learning from the real classroom. The former was too academic and theoretical, whereas the latter is practical. In terms of quality, it is as well $\cdots$ It is meaningful for us to stay in the same space with students and it was exciting to meet them. 
Even if Jinyoung points out the institutional inertia of student teaching, he said he could reflect on, during student teaching, what he is doing and what he wants to do through moral education. Quantity of student teaching does not necessarily equate to quality, but at least it provides opportunities for teacher development and teacher learning. In addition, student teaching provides preservice teachers with a chance to experience the gap between theory and practice. Darling-Hammond (1998) introduced the extended program "providing both education and subject-matter coursework that is integrated with clinical training in schools" (p. 8); it is implemented by over 300 Colleges of Education all over the U.S. In some cases, student teaching is being extended beyond the 4-year degree program, and includes a year-long school-based internship focusing on professional learning in practice.

Student teaching provides an opportunity to develop teacher identity and subject matter knowledge through practice. Moreover, preservice teachers can meet real students only through student teaching and internship. This is a good chance as well to understand students' educational, social, and cultural contexts.

\section{Significance of Psychological, Cultural, and Socioeconomic Understandings of Students' Contexts}

The lack of pedagogical learner knowledge appears to contribute to the gap between teacher preparation and the real classroom. As a result, participants agreed that at first they could not understand the students to whom they were teaching moral studies. Students live in different contexts from teachers in terms of social, cultural, and economic backgrounds. Participants want subject matter coursework to be integrated with content on understanding students. In teacher preparation, courses for teaching profession such as general education courses are compulsory for teacher qualification. However, participants shared that these courses are likely to be general, theoretical, and decontextualized. Accordingly, general pedagogical courses are not appropriately linked to PCK courses. Aram said:

I first worked at a technical high school. It was a shock to me. I cried for the first month. It was quite different from the school where I did my student teaching. They talked back to me using bad words. Some went to school by motorcycle and got punishment all day. At night they worked part time, even during the exam period. They were late for class and sometimes drunk. Teaching was so hard. 
Aram acknowledged that she never met students like this in her life. In teaching moral subjects and ethics, she never considered teaching students who are in different socioeconomic situations than herself. She adds that she lacks psychological understanding of her current students. Thus, a teacher without knowledge of her students cannot execute effective teaching.

Students' psychological, social, cultural, and economic backgrounds are not homogeneous with teachers. In addition, the educational and social contexts of current students are very different from teachers' adolescent days. Wooyoung showed a similar experience to Aram's:

My first appointment was at a public technical high school. This was an unfavorable school among teachers because of the underprivileged environment. Many economically disadvantaged students attended this school. Their family backgrounds were different and unique in terms of income and marital status. If I were in that situation, I might not survive. Many students got in trouble. These students changed my mind about being a teacher $\cdots$ Now I have come to understand their situation. At first, I blamed the students who made trouble, but now I am trying to understand their circumstances $\cdots$ With regard to moral studies, they are not interested in learning this subject. These topics are not related to their life experiences outside the classroom. It is so hard to teach the students who are not motivated to learn.

Students are situated in different socioeconomic and academic positions. Furthermore, teachers in secondary schools are increasingly exposed to multicultural student populations who have different ethnic, cultural, and linguistic backgrounds. In the U.S., with a large population of diverse students, sociocultural competence gets great attention in teacher education (Gay, 2005; Moll \& Arnot-Hopffer, 2005). Teacher education attempts to develop teachers' abilities to respond to shifting student demographics. This competence needs to be applicable to teachers in general, not to mention moral subject teachers. The necessity of contextual understanding for students frequently emerges throughout the data. Bori said:

We seem to enter the teaching profession without sufficient knowledge of our students. I heard from teachers that it is hard for us to understand students because most teachers have lived an easy life compared to students in general, particularly in terms of academic achievement. I agree with them. Teachers from the upper class or upper academic status cannot understand students in lower positions; they cannot grasp why they achieve poor grades and why they do not strive to learn. I witness this case frequently. 
Wooyoung experienced this gap when he worked for economically disadvantaged, low-performing students. His account coincides with Bori's experience in a general high school.

I felt the disparity between the teachers and the students. Teachers were mostly model students when they were in high school, without causing any trouble or punishment. However, half of the students in this technical high school make trouble. Teachers cannot understand their behaviors since they themselves did not experience them. Of course, we learned about student behavior in Educational Psychology but we mostly memorized theories. Actually, we did not learn about students from practice. It would be better for us to learn in real situations.

With regard to courses for the teaching profession, participants point out the decontextualization and standardization for the exam. These courses are not integrated in teacher knowledge for professional teaching. Teachers' subject matter knowledge does not merely include content knowledge; effective teaching is gained through interactions among teacher, student, and curriculum. As a curriculum agent, teachers do not implement passively the curriculum. On the basis of teacher knowledge as a professional, they exert an agency over curriculum.

\section{CONCLUSION}

This study is interested in PTE focusing on practical knowledge growth through pedagogical integration with content and practices. When novice teachers are confronted with teaching in the real classroom, quality teacher preparation can reduce the disconnection between the PTC and the real classroom. Such preparation can also improve teachers' professionalization when instructing a specific subject matter. Those who heavily rely on a textbook when teaching reveal that they lack PCK and practical teacher knowledge. Moreover, this study emphasizes importance of 'learning from practice' in the preservice teacher program. Test-based experiences, such as the Teacher Recruitment Exam, in the College of Education in Korea are compared to practice-based curriculum through intensive student teaching and internships.

Hence, this study explores novice teachers' experiences between the PTC and the first years of teaching. It focuses on illustrating and critically reflecting on teacher preparation 
for the moral subject using first-hand feedback from teachers themselves. Many studies in teacher education contend that teacher education needs to focus more on PCK through practice. In addition, such studies argue that through collaborative work between colleges and schools, extended student teaching and internships should be given to preservice teachers. These extended internships will allow student teachers to apply their course learning through practical experiences and develop substantial teacher knowledge.

According to the data drawn from interviews, however, the curriculum mismatch between the secondary school curriculum and teacher preparation program does not lead to PCK for professional teaching. The teacher preparation program is not closely linked to the secondary school curriculum, so it is hard to address the integrative content and methods in moral education. Thus, novice teachers feel a lack of teacher knowledge when they are confronted with teaching in the real classroom.

Thus, a frequently emerging issue is the request for PCK courses. Participants understand that the uniqueness of the College of Education involves teaching and learning. However, their experiences in teacher preparation are content-focused. Often, content courses are so narrowed and theoretical that it limits their practical knowledge which functions as curriculum gatekeeping. Furthermore, the program pays less attention to pedagogical integration while the overwhelming burden of the Teacher Recruitment Exam reinforces a content-based curriculum.

Lastly, novice teachers want to obtain teacher knowledge that is responsive to current students' sociocultural and psychological contexts. Students are situated in different contexts than from teachers' past experiences. Without psychological, sociocultural, and economic foundations of education, teaching is limited to decontextualized curriculum repetition. Pedagogical learner knowledge forms the foundation in teaching the subject matter.

Overall, this research identified a strong request for practice. For example, extended student teaching and other kinds of internships can provide an opportunity to reflect on teaching in the real classroom. Student teacher experiences depend on strong links between university and classroom, and on the supervising teachers' competence.

To summarize, on the basis of the qualitative data, this study suggests that; the PTC in moral education needs to properly respond to the secondary school curriculum; the PTC contributes to the growth of subject matter knowledge as well as teacher identity in teaching moral studies through integrated, extended PCK courses; the PTC is partly grounded in intensive teaching practices and internship experiences; and teacher preparation should integrate subject matter teaching with understandings of students' psychological, 
sociocultural contexts. Upon reflecting on PTE, future research needs to explore how the Teacher Recruitment Exam affects preservice teachers' identity and professional knowledge construction. Furthermore, it needs to determine the practical connection of this exam on the PTC in moral education. In addition to research on the Exam and the curriculum, further research into who is selected in the Department of Ethics Education and how these students are motivated to be moral subject teachers is also necessary. This study intends to draw attention on the PTC in moral education through the qualitative data and contribute to research in moral subject teacher preparation. Thus, lack of teacher identity as a moral subject teacher was revealed. However, this study points out its limitation that the uniqueness of teaching experiences in moral education was not specifically highlighted through the interview data. 


\section{References}

Bang, Y.-J., Lee, C.-J., Lee, J.-H., Park, H.-S., Park, D.-J., Chu, B.-W., Yoon, G.-Y., \& Byun, J.-H. (1993). A study on moral subject teacher evaluation in reference to foreign teacher education and teacher certification. Moral and National Ethics Education, 4, 55-97.

Cha, W.-G. (1995). A study on direction for development of teacher education in secondary moral and ethics subject matter. Research on Moral and Ethics Education, 6, 264-289.

Cho, Y.-D., Park, Y.-G., Sung, G.-H., Lee, S.-Y., \& Park, H.-N. (2010). The actual conditions of the multicultural education in elementary and secondary schools. Theory and Research in Citizenship Education, 42(1), 151-184.

Hwang, I.-P. (2007). A study on the improvement device of teacher certification system \& teacher education system in moral subject. Research on Moral and Ethics Education, 25, 49-80.

Im, Y.-G. (2005). The change of teacher education system for elementary and secondary moral education. Research on Moral and Ethics Education, 20, 161-190.

Jin, Y.-E., \& Jo, I.-J. (2001). The understanding of the subject matter teaching. Seoul: Hakjisa.

Lee, Y.-K. (2007). A problem and improvement in the education system of moral subject Teacher. Research on Ethics Education, 14, 295-308.

Pak, B.-K. (2007). Relevancy of the basic passing subjects of moral teacher's education course at South Korea. Research on Ethics Education, 13, 165-184.

Adler, S. (2008). The education of social studies teachers. In L. S. Levstik, \& C. A. Tyson (eds.), Handbook of research in social studies education, 329-351. New York: Routledge.

Chant, R. H. (2002). The impact of personal theorizing on beginning teaching: Experiences of three social studies teachers. Theory and Research in Social Education, 30(4), $516-540$.

Carl, A. E. (2009). Teacher empowerment through curriculum development: theory into practice ( $3^{\text {rd }}$ ed.). Juta Academic, Cape Town, South Africa.

Darling-Hammond, L. (1998). Teacher learning that supports student learning. Educational 
Leadership, 55(5), 6-11.

DeAngelis, K. J., Wall, A. F., \& Che, J. (2013). The impact of preservice preparation and early career support on novice teachers' career intentions and decisions. Journal of Teacher Education, 1-18.

Fontana, A., \& Frey, J. H. (2005). The interview: from neutral stance to political involvement. In N. K. Denzin, \& Y. S. Lincoln (Eds.), The Sage handbook of qualitative research, 695-727. Thousand Oaks, CA: Sage Publications.

Gay, G. (2005). Politics of multicultural teacher education. Journal of Teacher Education, 56(3), 221-228.

Glesne, C. (2011). Becoming qualitative researchers: an introduction (4thed.). Boston, MA: Pearson Education Inc.

Grimmett, P. P., \& MacKinnon, A. M. (1992). Craft knowledge and the education of teachers. Review of Research in Education, 18, 385-456.

Grossman, P. L. (1990). The making of a teacher: teacher knowledge and teacher education. New York: Teachers college press.

Heller, D. A. (2004). Teachers wanted: attracting and retaining good teachers. Alexandria, VA: Association for Supervision and Curriculum Development.

Kim, R.-Y., Ham, S.-H., \& Paine, L. W. (2011). Knowledge expectations in mathematics teacher preparation programs in South Korea and the United States: towards international dialogue. Journal of Teacher Education, 62(1), 48-61.

Mears, C. L. (2012). In-depth interviews. In J. Arthur, M. Waring, R. Coe, \& L. V. Hedges (Eds.), Research methods and methodologies in education, 170-176. Los Angeles, CA: Sage Publications.

Merriam, S. B. (2009). Qualitative research: a guide to design and implementation. San Francisco, CA: Jossey-Bass.

Moll, L. C., \& Arnot-Hopffer, E. (2005). Sociocultural competence in teacher education. Journal of Teacher Education, 56(3), 242-247.

Patton, M. Q. (1990). Qualitative evaluation and research methods ( ${ }^{\text {nd }}$ ed.). Newbury Park, CA: Sage publications.

Rubin, H. J., \& Rubin, I. S. (2005). Qualitative interviewing: the art of hearing data ( $\left.2^{\text {nd }} \mathrm{ed}\right)$. Thousand Oaks, CA: Sage publications.

Shulman, L. S. (1986). Those who understand: knowledge growth in teaching. Educational Researcher, 15(2), 4-14. 
Shulman, L. S. (1987). Knowledge and teaching: foundations of the new reform. Harvard Educational Review, 57(1), 1-22.

Thornton, S. J. (1991). Teacher as curricular-instructional gatekeeper in social studies. In J.P. Shaver(ed.), Handbook of research on social studies teaching and learning, 237-248. New York: MacMillan publishing company.

Van Hover, S. (2008). The professional development of social studies teachers. In L. S. Levstik, \& C. A. Tyson (eds.), Handbook of research in social studies education, 352-372. New York: Routledge.

- 논문접수 : 2013-08-30/ 수정본접수 : 2013-10-02/ 게재승인 : 2013-10-16 


\section{요 약}

교사양성 교육과정과 현장에서의 경험의 차이에 대한 중등 도덕과 신참 교사의 인식 연구

김영은

(텍사스주립대학교, 박사과정)

이 연구는 도덕과 교사양성 교육과정이 내용을 교과교육학적으로 통합하고 실제에 기반한 지 식의 성장에 중점을 두어야 한다는 데에 관심을 둔다. 신참 교사가 실제 교실에서 도덕과 수업 에 직면하였을 때, 질적으로 우수한 교사교육은 경험의 단절을 막고, 교사 전문성 향상에 기여 할 수 있다. 교사는 교육과정을 실행하고 재구성 하는 주체로서 교수내용지식과 실제적 교사지 식을 갖추어야 한다. 이러한 문제인식으로 이 연구는, 도덕과 교사교육과정을 비판적으로 숙고 하고, 관련 분야에 질적 경험연구 자료를 제공하기 위해서, 도덕과 신참 교사의 대학에서의 교 사교육과정과 실제 현장에서의 경험의 차이를 탐구하였다. 신참 교사는 가장 생생한 교사 양성 교육과정의 경험을 보유하고 있으며, 첫 몇 해 동안 대학에서 배운 바를 적용하려고 한다는 측 면에서, 질적 연구의 대상으로 적절하다고 판단되어 선택되었다.

인터뷰를 통해 드러난 내용은, 신참 교사들은 첫 몇 해 동안 도덕과 교사의 정체성의 부족과 실제적 교사지식의 부족으로 고민할 뿐만 아니라, 대학 교육과정과 현 중등학교 교육과정의 부 정합은 적절한 전문적 지식의 성장을 방해한다는 것이었다. 대학의 교사양성 교육과정은 현 중 등학교 교육과정을 내용의 측면에서 그리고 다양한 학생이해의 측면에서 제대로 반영하지 못하 는 면이 많았다. 또한 교수내용지식 강좌는 여전히 큰 비중을 차지하지 못하고 다른 과목과 유 기적으로 통합되지 못하는 측면이 많았다. 교수 중심의 지나치게 학문적이거나 이론적인 분야에 국한된 수업이나 방대한 분량의 기계적 내용 습득에 주력하는 임용고사 위주의 대학 교육과정 경험은 예비교사들의 전문적 교사지식을 습득하는 데에 도움을 주지 못하였다. 그리하여 예비교 사 교육은 교육적 실제를 통해 교수내용지식의 성장에 중점을 두고, 대학과 현장 학교 간의 체 계적인 공조를 통해 좀 더 실효성 있고 연장된 형태의 교생실습과 인턴 교사교육을 통해 이루어 져야 한다는 점을 제안하였다.

주제어: 교사양성 교육과정, 신참 교사의 경험, 실제를 통한 배움, 학생이해지식, 사회문화적 역량, 교수내용지식, 중등 도덕과 교사교육 